\title{
A Synoptic and Dynamic Study on the Three Dimensional Structure of Mesoscale Disturbances Observed in the Vicinity of a Cold Vortex Center
}

\author{
By S. Matsumoto, K. Ninomiya and T. Akiyama \\ Meteorological Research Institute, Tokyo \\ (Manuscript received 28 July 1966)
}

\begin{abstract}
A family of remarkable mesoscale disturbances was observed on the western side of the cold vortex of smaller scale which had passed the central Japan on January 16, 1965. The cold air is bounded by a steep inversion layer and the mesoscale undulation is superposed on its western slope. By the special aerological observation network whose covering area is about one fifth of the routine network, a characteristic wind field is revealed. It is convergence and cyclonic vorticity in the lower part and divergence and anticyclonic vorticity in the upper part of the cold air and it implies a mesoscale convective system. Correspondingly lower level depression and upper level high are found in the pressure field.

A series of disturbances of a 2-3 hour period which moved eastward with a velocity of $85 \mathrm{~km} / \mathrm{hr}$ and was closely related to the precipitation was revealed in the surface pressure field. Detailed quantitative analyses were made on the pressure and wind anomaly field. The analyses were obtained by applying the $2.5 \mathrm{hr}$ running mean in order to pick up the disturbances mentioned above. The scale of disturbance was found to be of the order of $250 \times 10^{8} \mathrm{~m}^{2}$. The convergence area followed the pressure depression with positive vorticity area to the south and negative vorticity field to the north. Thus the principal balance of the vorticity equation was established between the vorticity change and the twisting term. While the balance of the divergence equation was approximately obtained between the divergence change and the pressure field as was suggested in our previous paper. However a discrepancy was observed mainly in the convergent area. This fact is well explained by introducing the effect of cumulus convection activity in that area.
\end{abstract}

\section{Introduction}

Owing to the endeavours by many authors, there is little doubt in the fact that the heavy snowfall observed in the Hokuriku district, the Japan Sea coastal region of the central Japan, is closely related to the invasion of upper cold vortex, which have been studied experimentally, synoptically and statistically (e.g. Fukuda, 1960 and 1965 ; Miyazawa, 1962). The authors also studied the three dimensional structure of cold vortex (Matsumoto et.al., 1965) and the mesoscale disturbance observed in the vicinity of its central area (Matsumoto and Ninomiya, 1965) in relation to the heavy snowfall.

Recently the role of small scale disturbances has been realized among synoptic meteorologist (e.g. Miyazawa, 1961 ; Fukuda, 1965) and the existence of circular vortex of a size of less than $100 \mathrm{~km}$ is now verified by radar observations (Miyazawa, 1966).

In this paper, a further example of mesoscale disturbance will be analysed in more detail by using the data obtained by the Heavy Snow Storm Project Observation in 1965. (The Project observation has been carried out since 1963).

The aerological network of 1965 is given on Fig. 1. Black circles indicate routine aerological stations and white circles project aerological stations. During a week period ending on 00 GMT (09 LST) January 21, 1965, 6 hourly rawinsonde observations for 6 days and 3 hourly rawinsonde observations on the last day were performed at Wajima $\left(136^{\circ} 54^{\prime} \mathrm{E}\right.$, $\left.37^{\circ} 23^{\prime} \mathrm{N}\right)$, Aikawa $\left(138^{\circ} 15^{\prime} \mathrm{E}, 38^{\circ} 01^{\prime} \mathrm{N}\right)$, Nagaoka $\left(138^{\circ} 50^{\prime} \mathrm{E}, 37^{\circ} 27^{\prime} \mathrm{N}\right)$ and Toyama $\left(137^{\circ} 12^{\prime} \mathrm{E}\right.$, 


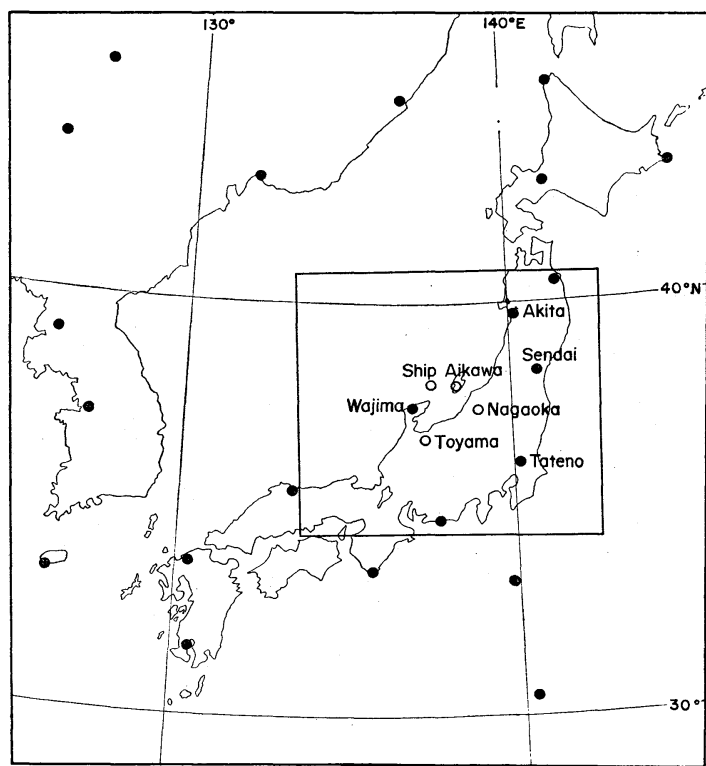

Fig. 1. Aerological station map. Black circles and white circles indicate routine stations and project stations respectively.

$\left.36^{\circ} 42^{\prime} \mathrm{N}\right)$. These stations are all distributed over coastal region of Hokuriku District and the covering area is $119 \times 10^{8} \mathrm{~m}^{2}$ which is about one fifth of a triangular area made by routine stations. Since this period was scheduled within the IQSY observation interval, 6 hourly rawinsonde data are also available from conventional stations. The meteorological observation ship "Seifumaru" made further off-

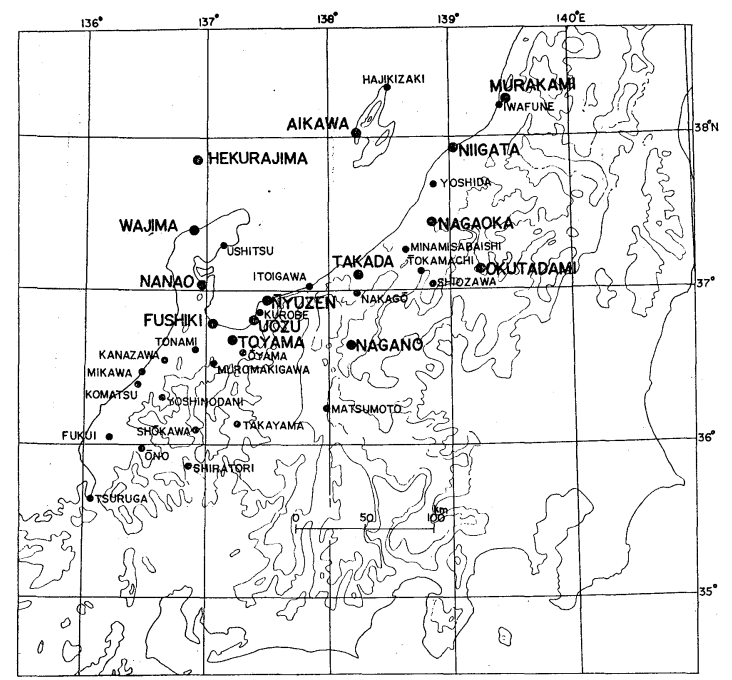

Fig. 2. Surface synoptic station map. $500 \mathrm{~m}$ and $1000 \mathrm{~m}$ contours are entered. shore radiosonde observations.

The surface observation network being used for synoptic mesoscale analysis is given in Fig. 2. Larger circles appearing on this figure indicate stations selected for the purpose of making detailed dynamic analysis. Because of the snow region, were used recording raingages specially designed for measuring the amount of precipitation. In addition, a weather radar was in operation.

\section{Synoptic situation}

During a week project observation, the most intense snowfall took place on January $15 \sim 16$, 1965. 6 hourly precipitation at representative stations is given on Fig. 3. The maximum precipitation intensity in the area was observed in Nagaoka at 08 LST January 16 . It amounted to $8 \mathrm{~mm} / \mathrm{hr}$ which is considerably large value for the snowfall intensity.

Weather charts on various levels at 09 LST January 16 are presented in Fig. 4. Only the situation in smaller area as indicated by a square in Fig. 1 is given here. The low pressure on the surface had already passed over Japan Islands and a prevailing north-westerly monsoon was about to start. Correspondingly the upper trough was located just above the Japan Islands.

The most striking feature in the synoptic pattern is found on the temperature field which is shown by dashed lines. A remarkably low temperature area appears on $500 \mathrm{mb}$ chart as almost always does in case of heavy snowfall. The scale of this cold air, however, was

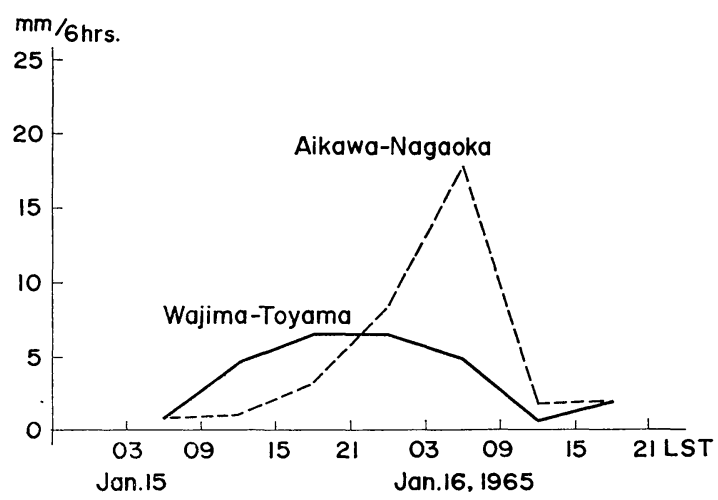

Fig. 3. 6 hourly precipitation at western stations Wajima and Toyama (full line) and at eastern stations Aikawa and Nagaoka (dashed line) during January 15 16, 1965. 

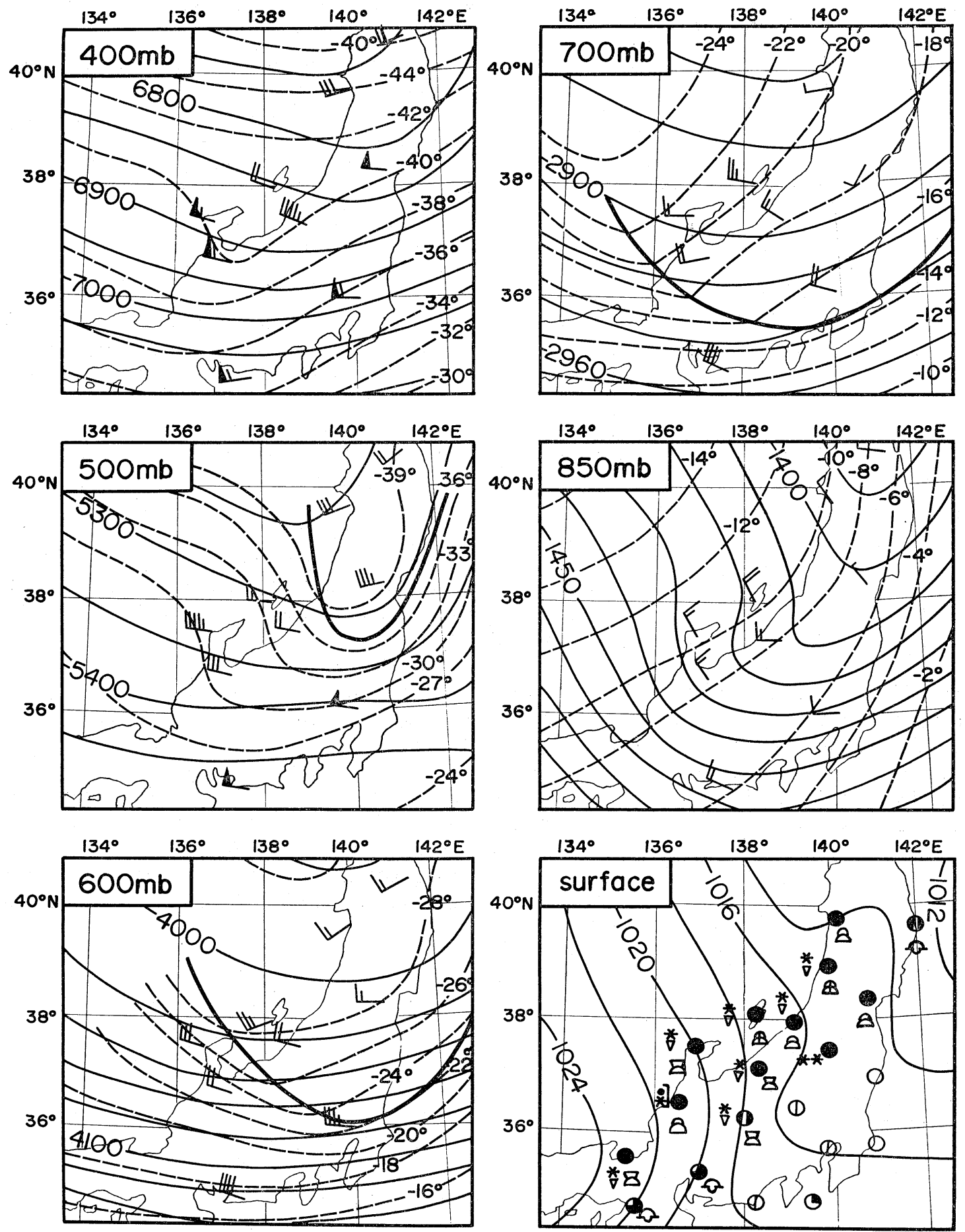

\section{O900LST Jan. 16, 1965}

Fig. 4. Various leve1 charts at 09 LST January 16, 1965. Full lines and dashed lines are pressure (in $\mathrm{mb}$ ) or pressure height (in $\mathrm{gpm}$ ) contours and isotherms (in ${ }^{\circ} \mathrm{C}$ ) respectively. Heavier lines indicate the inner boundary of stable layer which bounds the cold dome. Wind barbs are given on upper charts (full barb: $10 \mathrm{~m} \mathrm{sec}^{-1}$ ) and the weather is entered on the surface chart. 
so small that the dense network of our project observation can scarcely detect its existence. The heavier lines entered on $700 \mathrm{mb}, 600 \mathrm{mb}$ and $500 \mathrm{mb}$ chart indicate the inner boundary of stable layer surrounding the cold air, by which the smallness of its scale is seen. Further detail will be discussed in the following section.

The jet stream is located to the south of the cold air at a higher latitude than the normal position.

\section{The behavior of the cold dome}

In the previous papers (Matumoto et.al., 1965 ; Matsumoto and Ninomiya, 1965) the structure of cold domes was studied in relation to heavy snowfall. In the case of January $15-16,1965$, a distinct boundary layer was found around the cold dome although it is of very small scale.

Defining the boundary surface by the lower surface of the stable layer, the geometry of the cold dome is shown in Fig. 5. Dashed lines shows the displacement of the dome at every 6 hourly observation time. Fig. 6 and Fig. 7 are presented to illustrate the development of the cold dome. In Fig. 6 are shown the successive horizontal cross sections at $550 \mathrm{mb}$ level, and the vertical zonal cross sections at $38^{\circ} \mathrm{N}$ are given in Fig. 7. The vertical dashed lines indicate the location of Japan Island at $38^{\circ} \mathrm{N}$ and the left line roughly

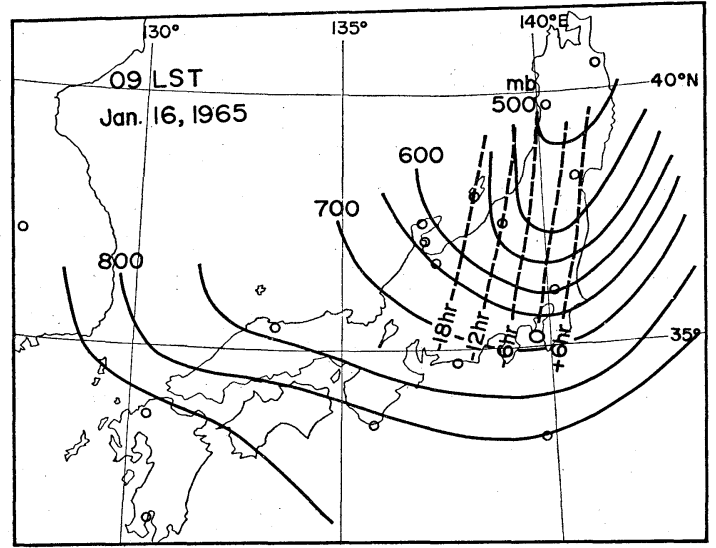

Fig. 5. Cold dome geometry at LST January 16, 1965. Full lines are the contours of the height of dome labelled with pressure height and the displacement of dome is entered by dashed lines in every 6 hours. corresponds to the Japan Sea coast line of Hokuriku District. As will be discussed in the following sections, a series of mesoscale dis-

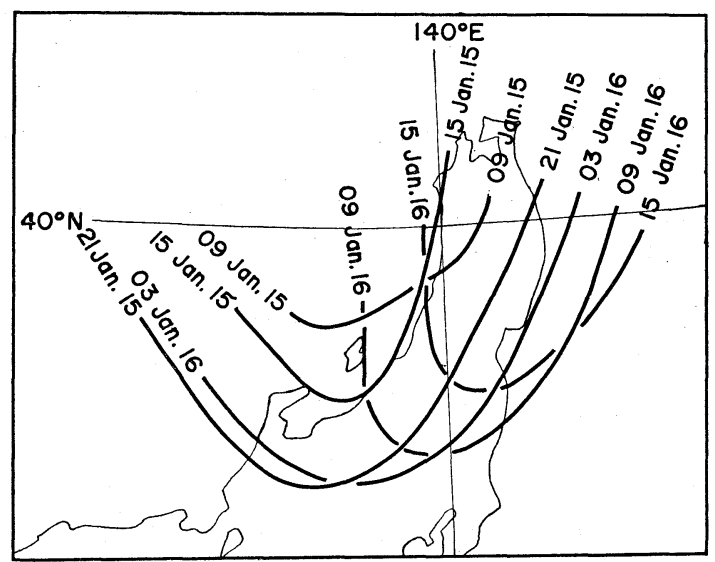

Fig. 6. The horizontal cross sections of the cold dome at $550 \mathrm{mb}$ level in every 6 hours interval.

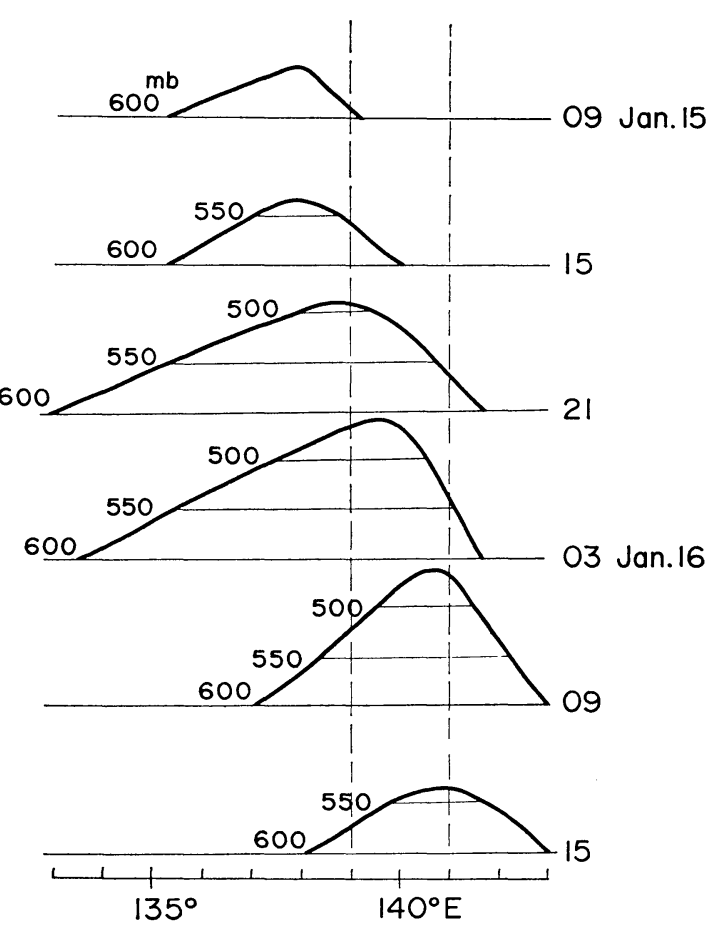

Fig. 7. The vertical cross sections of the cold dome at $38^{\circ} \mathrm{N}$ latitude circle in every 6 hours interval. The geometry of the cold air above $600 \mathrm{mb}$ is given here with the indications of pressure heights. Dashed lines show the locations of west and east coast lines of the Japan Islands at $38^{\circ} \mathrm{N}$. 
turbances accompanied by heavy snowfall was observed in this area and the last, and at the same time the most severe, spell hit the very locality indicated by the left side dashed line in Fig. 7 at 09 LST January 16. It is seen from Figs 6 and 7 that the cold air was shrinked and upheaven by that time and, after that, lost the potential energy quite rapidly. The disturbance under the question took place in the cold air at its backward area having a steep upslope.

\section{Finer structures of the cold dome as revealed by the dense rawinsonde network}

As mentioned in Section 1, a dense rawinsonde network was set up in the coastal area of Hokuriku District (see Fig. 1). This network had successfully caught a quite interesting field of meso-scale convective motion at 09 LST January 16.

Let us, first of all, see the structure of cold dome boundary. Fig. 8 gives examples of ascent curves at Sendai (routine station), Nagaoka and Toyama which are lined up approximately on a straight line. We can see well defined lower and upper boundaries of

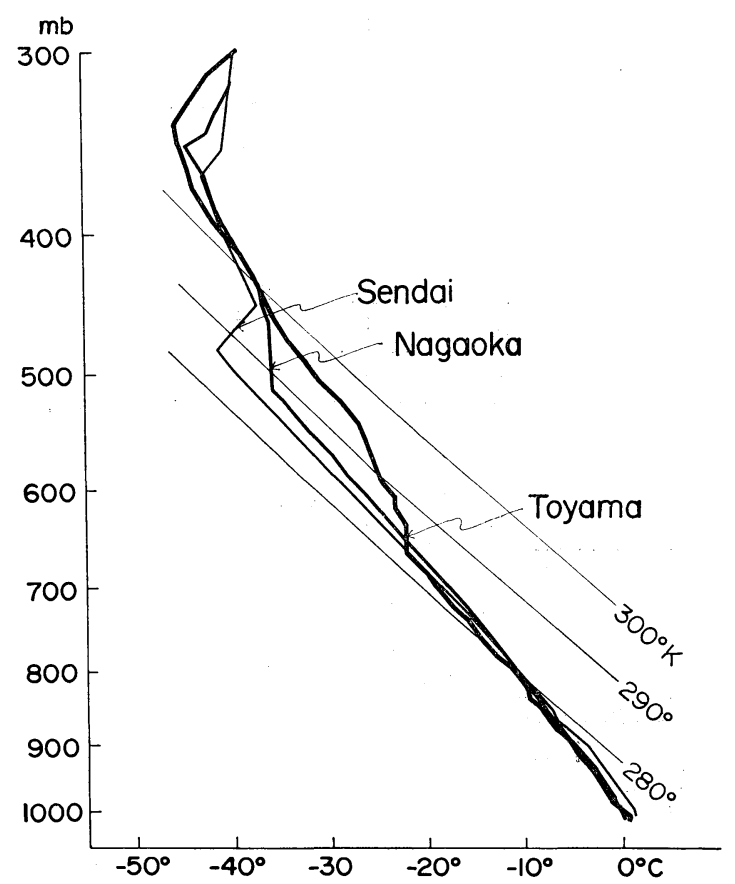

Fig. 8. The vertical temperature distributions over Sendai, Nagaoka and Toyama (see Fig. 1) at 09 LST January 16, 1965. The thin straight lines are iso-potential temperature lines.

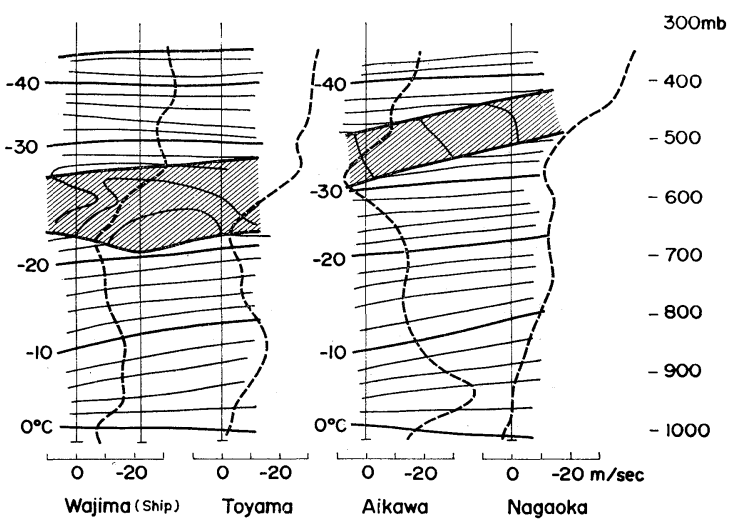

Fig. 9. The vertical cross sections at 09 LST January 16, 1965 along the westen side (the left figure) and the eastern side (the right figure) of the dense rawinsonde network. Full lines are the isotherms labelled in ${ }^{\circ} \mathrm{C}$ and the cold dome boundary layer is hatched. Dashed lines show the wind component in the direction of $330^{\circ}$ (perpendicular to the coast line) and the scale is given on the bottom.

the stable layer, having remarkably uniform equivalent potential temperatures. The temperature distributions below and above these boundary surfaces are also considerably uniform. In Fig. 9 are given the local vertical cross sections perpendicular to the coastal line, one westside across Wajima-Toyama line (the left fugure) and the other eastside across Aikawa-Nagaoka line (the right figure). The cold dome boundary layer which is hatched in the figure is seen to have a steep upslope towards east as mentioned in the previous section. The temperature gradient perpendicular to the coastal line is quite characteristic inside of the cold air. Since Wajima and Aikawa are located in the Noto Peninsula and Sado Island, respectively, the stratification is very much influenced by the predominant supply of heat from the warm sea surface, so that the instability is accumulated in the lowermost layer of the cold air. On the other hand, at Nagaoka and Toyama which are located inland, the whole air column in the cold air is generally stratified wet adiabatically (see also Fig. 8), implying the effect of precipitation.

Detailed situation around the boundary layer is reproduced in Fig. 10. The horizontal cross section of boundary layer at the level of 


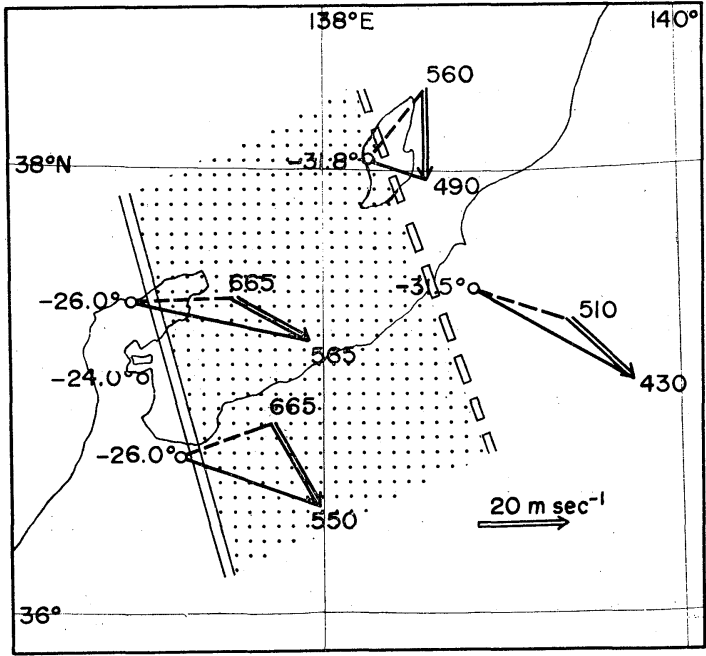

Fig. 10. The horizontal temperature field and wind shear around at the level of cold dome boundary 09 LST January 16,1965 . The cold dome boundary layer at $550 \mathrm{mb}$ level is hatched. Double full line and double dashed line are the upper and lower boundary respectively. The wind at the upper and lower boundary are shown by full lines and dashed lines labelled with pressure height respectively. The vertical wind shear in the boundary layer is given by double arrows whose magnitude is given in the figure.

$550 \mathrm{mb}$ is stippled, the upper and the lower boundary being indicated by a double straight line and a double broken line respectively. The temperature on this level is entered. The wind vectors at the upper boundary and the lower boundary are shown by full lines and dashed lines respectively labelled with the pressure heights. It is seen that the westerly wind having north component is prevailing above the cold dome boundary while, as to the wind in the upper part of the cold air, the south component is remarked. Thus, there exist a strong wind shear as indicated double lines in Fig. 10. It is interesting to notice that the magnitude of the vertical shear is in good agreement with the thermal wind due to the strong temperature gradient of $4.5^{\circ} \mathrm{C} /$ $100 \mathrm{~km}$ even though the wind itself is by no means geostrophic.

A remarkable divergent wind field is seen in the layer just below the cold dome boundary surface (see Fig. 10). The vertical distribution of the wind component is given in Fig. 9 by broken lines. The component is taken in the direction of $330^{\circ}$ which is perpendicular to the coast line and approximately agrees with the direction of either from Toyama to Wajima or from Nagaoka to Aikawa. It is suggested that divergent field in the upper layers and, at the same time, convergent field in the lower layers might be found especially in the eastern area of our domain.

As a matter of fact the characteristic distribution of divergence mentioned above is found within the cold air. The divergence field shown in Fig. 11 is obtained by using 4 point observation at 09 LST January 16 . The covering area is $119 \times 10^{8} \mathrm{~m}^{2}$ which seems to be a little larger for discussing mesoscale phenomena quantitatively. But still it is of value to assert the existence of mesoscale convective system since we can find a remarkable mesoscale surface disturbance in the same region and on the same time. Discussions on this subject will be given in the following sections. The vorticity field entered by dashed line in Fig. 11, too, shows noteworthy distribution which is quite similar to a synoptic scale convective system, i.e. cyclonic circulation in the lower layer and anticyclonic circulation in the upper layer. It should also be pointed out that all these phenomena are bounded by cold dome boundary layer which is indicated by hatches in Fig. 11.

The convective vertical motion field is

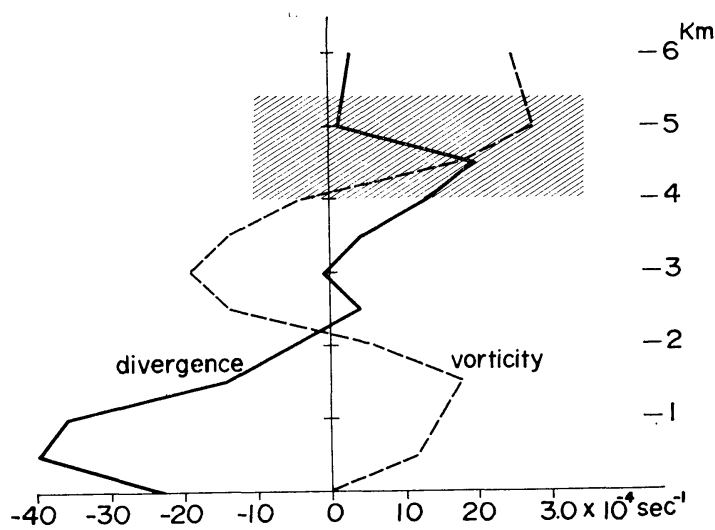

Fig. 11. The vertical distribution of divergence (full line) and vorticity (dashed line) computed by 4 point wind observation at 09 LST January 16, 1965. The level of cold dome boundary layer is hatched. 


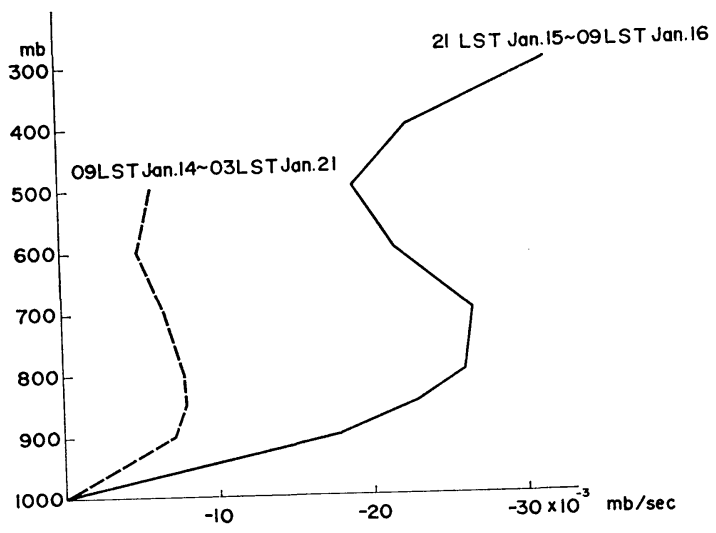

Fig. 12. The vertical velocity for the period under the influence of cold dome (full line) and for the whole period of observation (dashed line).

observed within the cold air. The full line in Fig. 12 is the vertical velocity averaged for the period from 21 LST January 15 to 09 LST January 16 when our region had been covered

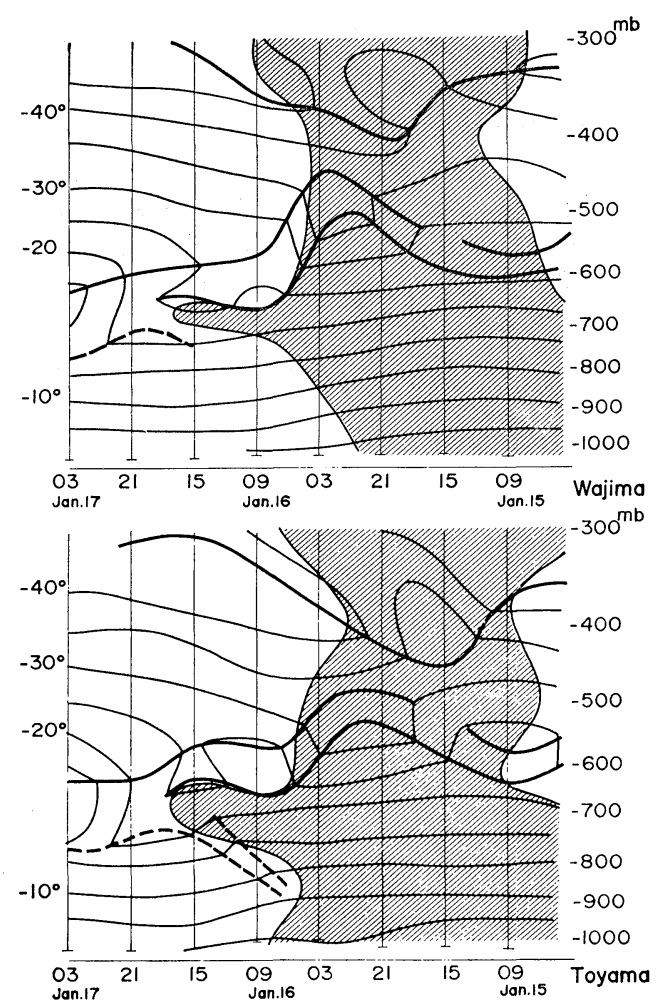

by the cold dome. The minimum appearing at $500 \mathrm{mb}$ level means the upper boundary of the convective motion. The average over a week of the project observation is given by a dashed line (c.f. Matsumoto, 1967). Comparing the two curves we can see that the top of convective motion is higher for the selected period under consideration. It should of course be born in mind that the values themselves in the higher levels are subject to errors caused by the balloon drifting since the observation network is of smaller scale (see Matsumoto and Ninomiya, 1963).

The vertical time sections at each of four project rawinsonde stations are given in Fig. 13 for the period from 09 LST January 15 to 03 LST January 17 . The cold dome boundaries indicated by heavier full lines show remarkable undulations especially to the rear side of the dome. This fact would presumably be related to the mesoscale surface pressure

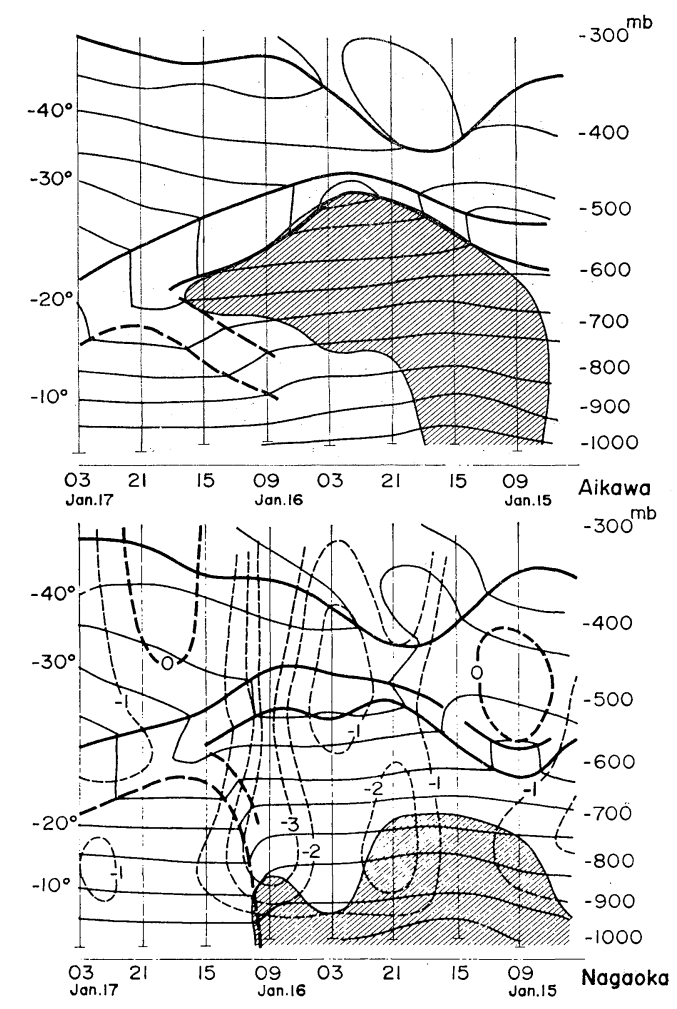

Fig. 13. The vertical time section at Wajima, Toyama, Aikawa and Nagaoka. Full lines are isotherms labelled in ${ }^{\circ} \mathrm{C}$. Heavy full lines and heavy broken lines show the stable boundary layer. The vertical velocity computed by these 4 point wind observation is entered in the Nagaoka time section (the lower right figure) labelled in $10^{-2} \mathrm{mb} / \mathrm{sec}$. The area of southerly wind component is hatched. 

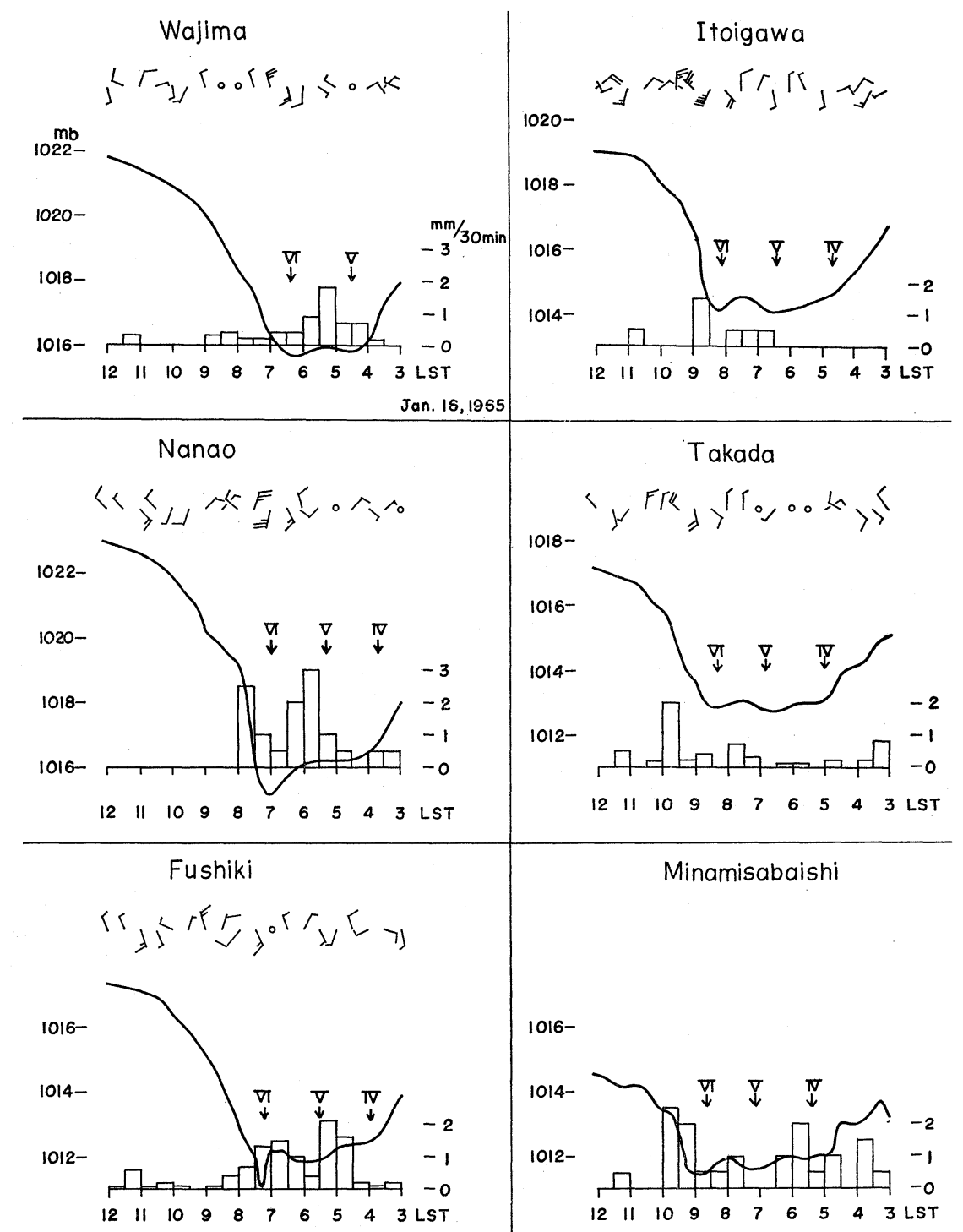

1016-
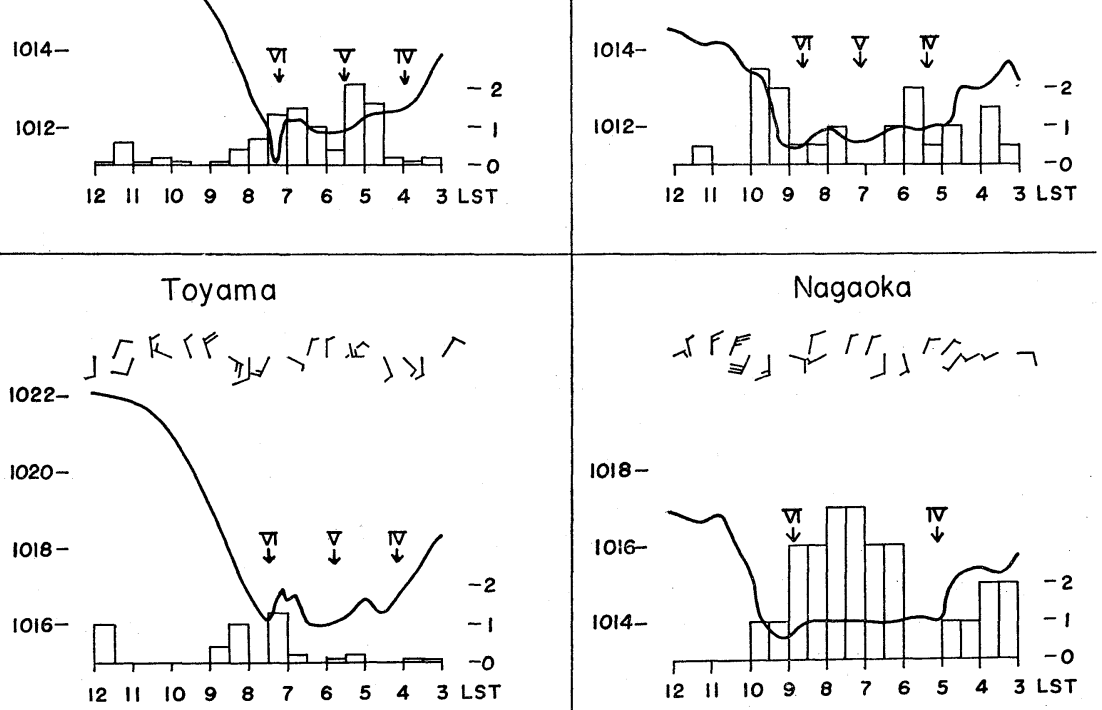

$1018-$

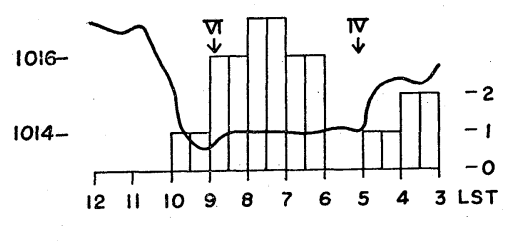

Fig. 14. Enlarged barograph records, the amount of precipitation in $30 \mathrm{~min}$. interval and the anormaly wind (a full barb indicates $2 \mathrm{~m} / \mathrm{sec}$ ) at selected stations in Hokuriku District. 
disturbance which will be discussed in the following sections. The heavier broken lines are used to indicate the boundary surface on which the potential temperature is more or less similar to that of the maritime inversion layer rather than to that of the cold dome boundary layer. The former is unexceptionally observed over the Japan Sea when the north westerly monsoon prevails.

The hatched areas in Fig. 13 show that the winds have southerly component. It is seen that the boundary layer system separates the wind system as well as the temperature field, and that the southerly wind prevails within the cold dome except that the northerly wind is observed in the lower layer towards off sea and in the higher layer towards land showing the predominant convective activity.

The vertical motion computed by 4 point wind observations is entered in the time section at Nagaoka (lower right figure of Fig. 13). The upward motion prevails in the core region of the cold dome just as shown for many other cases (see e.g. Matsumoto et al., 1965). This fact implies the production of potential energy of the cold dome. However, we can see, at the same time, some contribution to the kinetic energy release within the cold air since the upward motion seems to be larger in the warmer area.

The general feature of the cold dome structure is seen commonly on the 4 time sections.

\section{A family of mesoscale disturbances forerunning the cold air outbreak}

As is stated in the previous sections, the monsoonal outbreak was preceeded by the upper cold vortex which was of a very small scale and by the synoptic cyclone in front of it. The approximate time of occurrence in Hokuriku District is 15 LST January 15 for the transit of surface cyclone, 21 LST January 15 for the transit of the cold dome center and 09 LST January 16 for the cold air outbreak respectively. The mesoscale disturbances and associated heavy snowfall took place within several hours under the influence of upper level cold dome mentioned above. Quite a similar situation had been studied (Matsumoto and Ninomiya, 1965).

The discontinuous temperature change due to the cold air outbreak was not observed on the surface probably because the air very close to the warm sea surface is modified, but the temperature at the higher levels and wind did undergo a change.

The most remarkable change was observed on the surface pressure field. Examples of the barograms at selected stations are reproduced in Fig. 14. The striking features are a sudden rise of pressure at 07 09 LST and a periodic fluctuation in the preceeding several hours with a period of $2 \sim 3$ hours. The amount of precipitation and wind entered in this figure also show up a fluctuation correspondingly.

On account of the fact that there existed a period of $2 \sim 3$ hours, let us apply a 2.5 hour running mean on the time series at $30 \mathrm{~min}$ interval. Then we can separate the disturbance by taking the anomaly series. This method, first introduced in the author's previous paper (Matsumoto and Ninomiya, 1965), will be applied in the following discussions.

The isoplet in Fig. 15 is the time section of surface pressure anomaly from 21 LST January 15 to 12 LST January 16 . The stations are approximately lined up along the coast from WSW to ENE. It is clearly seen that about 6 progressive disturbances are detected in 12 hours. The negative anomaly area is hatched in this figure and will be
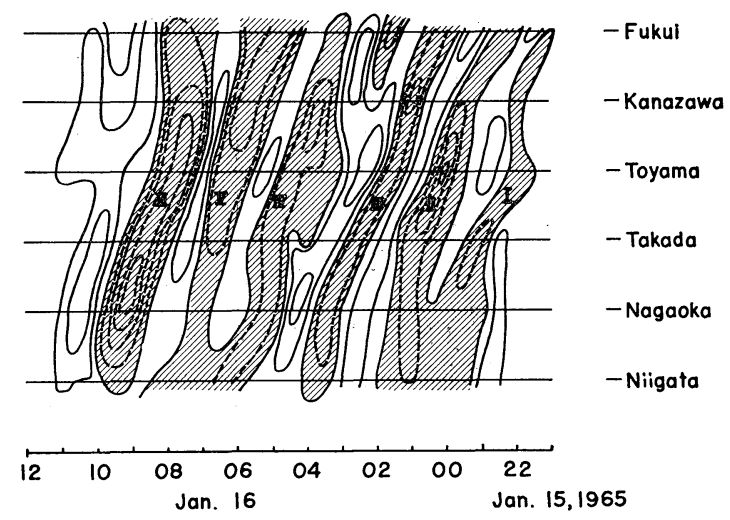

Fig. 15. The time section of anomaly surface pressure from 21 LST Jan. 15 to 12 LST January 16,1965 . The observation stations (up to down) are located along the coastal line of Hokuriku District from WSW to ENE. Contours are drawn in every $0.2 \mathrm{mb}$ and negative anomaly areas are hatched. The Roman numerals indi. cate the system number. 

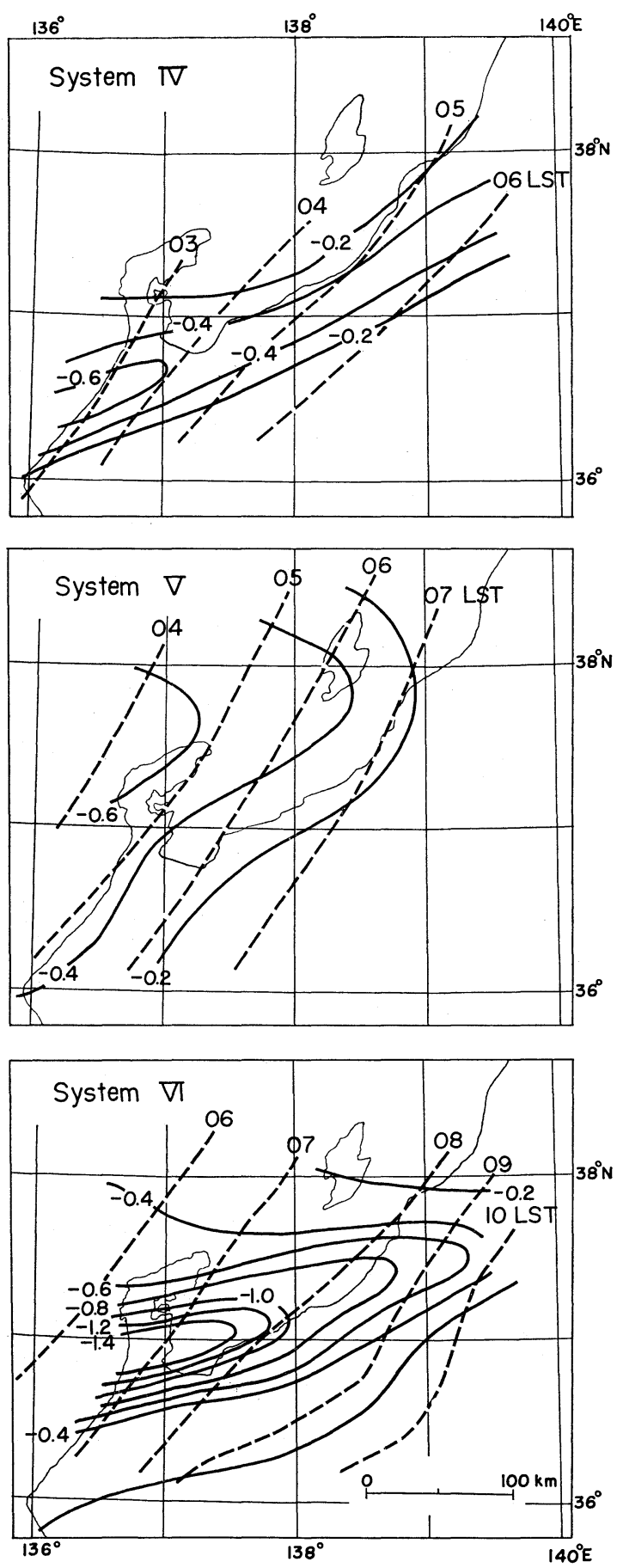

Fig. 16. The isochrones of minimum anomaly pressure (dashed lines) labelled with local times and the contours of minimum anomaly pressure values (full lines) for the disturbances, system IV, system V and system VI defined in Fig. 15. identified by system I to system VI hereafter. The system numbers are entered in Fig. 14 too. Among 6 well defined disturbances, the last system VI is the most significant one on which detailed synoptic and dynamic discussions will be given later.

In Fig. 16 are given the maximum value of the negative anomaly pressure and its isochrone for the system IV, system V and system VI. It is seen that these disturbances propagated eastward having a slight northward component with the phase velocity of $85 \mathrm{~km} / \mathrm{hr}$ and that they were weakened towards inland.

The direction of propagation and the phase velocity are in good agreement with the wind in a thin layer around $700 \mathrm{mb}$ level which lies just beneath the cold dome boundary and above the stable layer of cold air outbreak (see Fig. 13). Meanwhile, the displacement of individual echo cells on the radar scops is also well explained by this wind as is shown in Fig. 17. Here are given the trajectories of sample echo cells observed in the region of disturbances. It should be noted that the height of echoes and that of the clouds are presumably about $700 \mathrm{mb}$. A good relationship between the individual echo cell movement

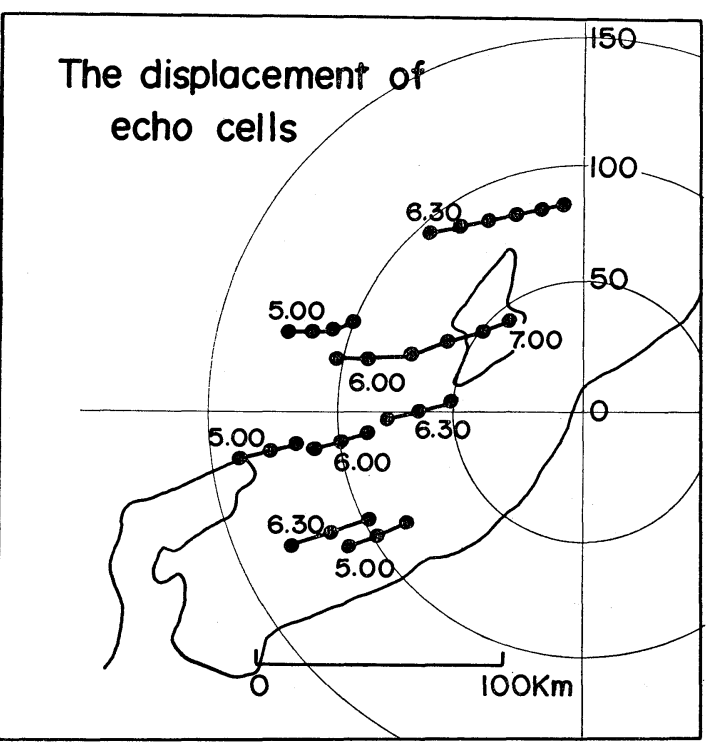

Fig. 17. Trajectories of sample echo cells selected in the area of disturbance system V. The successive black circles indicate the positions of echoes at every $15 \mathrm{~min}$. and are labelled with times. 
and the wind at the echo height is recognized in many of cases.

\section{Detailed mesoscale analysis on the pres- sure depression preceeding a sudden pres- sure rise}

In this section detailed discussions will be made on the mesoscale disturbance denoted as "system VI". Let us, first of all, construct the mesoscale maps of anomaly field at every 30 min. interval. In Fig. 18 the contours of anomaly pressure are drawn in every $0.2 \mathrm{mb}$ (broken for negative values). Anomaly wind field and amount of precipitation in preceeding $30 \mathrm{~min}$ are also entered. The distribution is quite similar to that obtained previously (Matsumoto and Ninomiya, 1965). The scale, the amplitude and the phase velocity
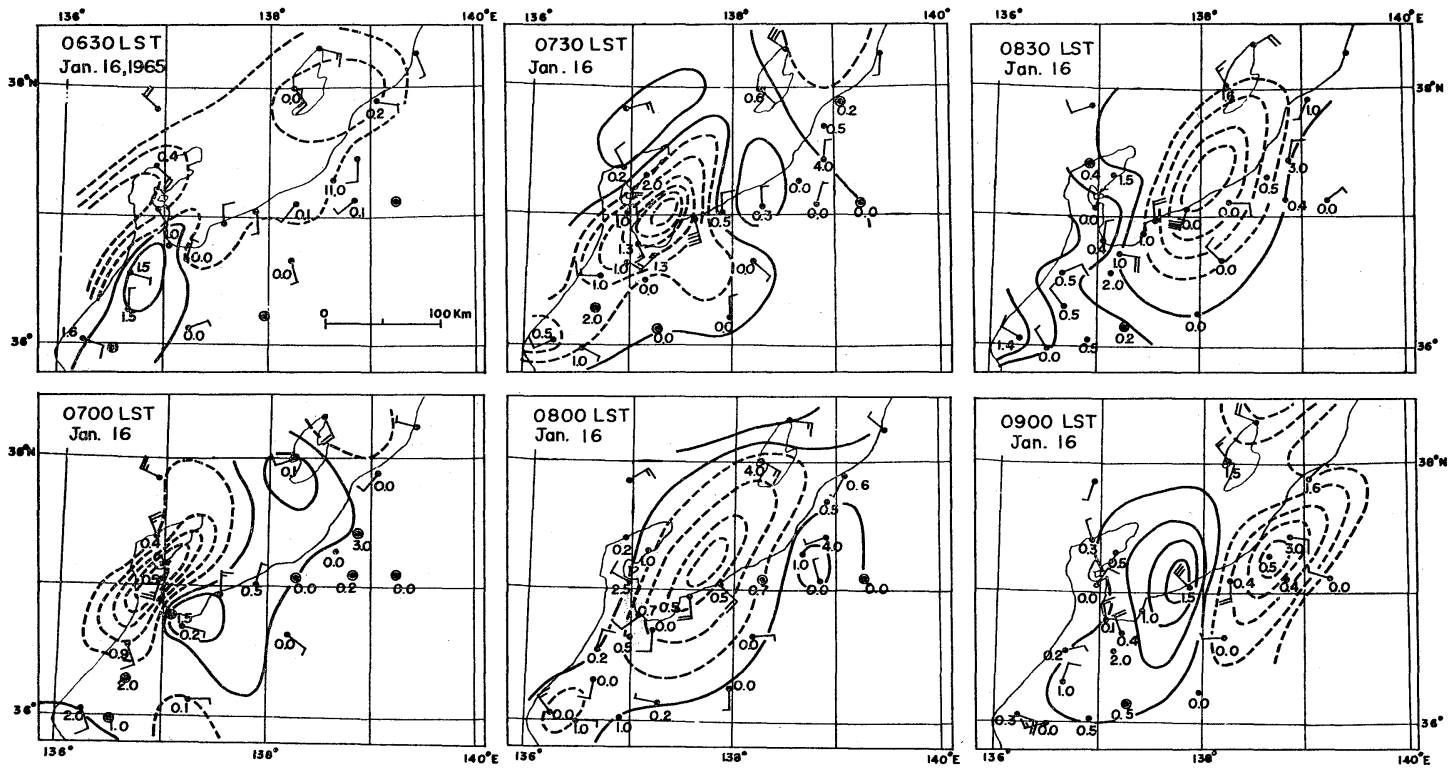

Fig. 18. The anomaly surface pressure distribution and anomaly wind field at every $30 \mathrm{~min}$. from 0730 LST to 0900 LST January 16, 1965 . The figures with decimal points are the amount of precipitation in preceeding $30 \mathrm{~min}$. Contours are drawn in every $0.2 \mathrm{mb}$ (broken for negative values). A full wind barb indicates $2 \mathrm{~m} / \mathrm{sec}$.

are about the same. The trajectory of minimum pressure in this case is experimentally well known as the most frequent path of radar echoes.*

In order to see the life time of this disturbance, the hourly observations are collected from wide area. Here the amount of pressure rise in one hour and the time of occurrence of minimum pressure are to provide the indication of life history of the disturbance. Fig. 19 shows the isochrone of minimum pressure occurrence and the maximum amount of pressure rise in one hour. The smaller area surrounded by dashed line is the area of

* On this subject, the paper will soon be written by Yanagisawa. The reasoning is tentatively considered as the orographic effect. detailed analysis. Obviously the distribution is in good agreement with that given on the bottom of Fig. 16. The small black circles in Fig. 19 show the distribution of hourly observing synoptic stations. Because of the sparseness of data in the Japan Sea area the analysis cannot be made very accurately. However, it may be said that the disturbance under consideration was originated off the coast of Japan Sea to the west of about $135^{\circ} \mathrm{E}$ where the effect of prevailing warm current is expected. The maximum intensity is observed over the neck of Noto Peninsula at about 07 LST and then the disturbance is weakened. The life time is provably of the order of 10 hours which is reasonable for this scale of disturbance (Matsumoto, 1966). 


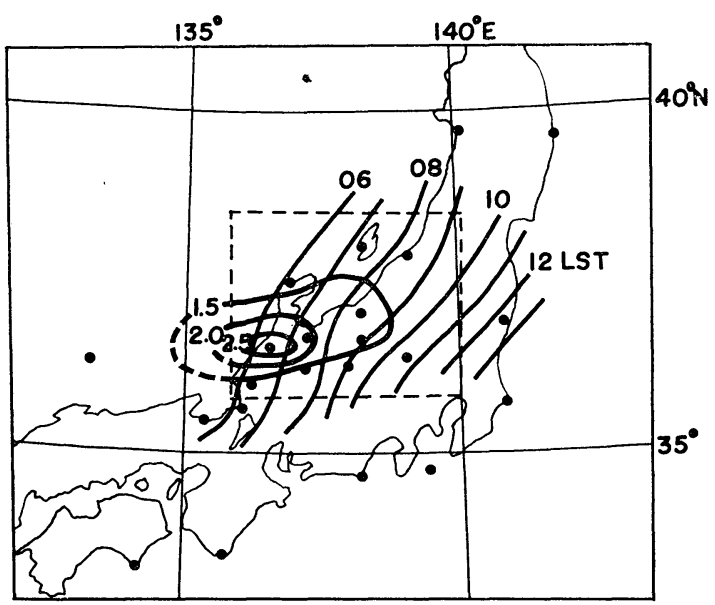

Fig. 19. Isochrones of minimum surface pressuse labelled with local times and contours of presure rise in the following 1 hour labelled in $\mathrm{mb}$ obtained by hourly observations. Black circles and a square given by dashed lines show the hourly observation stations and the area in which detailed analyes are made.

The fact that the disturbance was at mature stage and moved steadily over the area under consideration is favorable for applying the technique of mesoanalysis set up by Fujita et al. (1957). The difficulty arising from the sparse data coverage will thus be covered by the time and space transformation applied for about an hour interval.

Another difficulty is the standardization of the data. Since the absolute value obtained by self-recording equipments is usually less reliable and the elevation correction causes sometimes serious errors, the authors (Matsumoto and Ninomiya, 1965) introduced the anomaly method by taking 5 terms running mean on the data, say, at 30 min interval. It would be reasonable to make the origin of the time series adjustable so as to fit the sharp pressure minimum which may happen at an arbitrary time.

In Fig. 20 are presented thus obtained composite maps at 0730 LST and 09 LST January 16. The negative anomaly pressure is shown by full lines in every $0.2 \mathrm{mb}$. The dashed lines on 0730 chart (upper) are reproduced from 09 chart (lower). The stations selected for this analysis are shown by black circles. The anomaly winds are also entered in this figure. The wind barbs given at positions
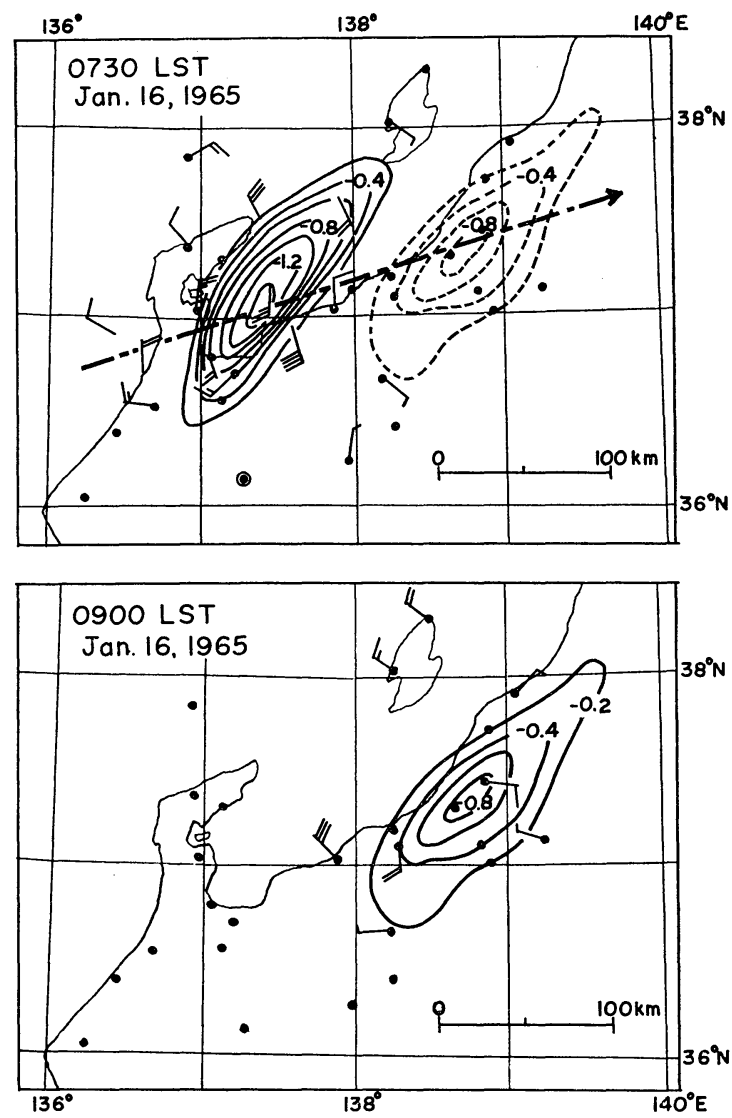

Fig. 20. The anomaly low pressure area and anomaly wind field at 0750 LST (upper figure) January 16, 1965 . Contours are drawn in every $0.2 \mathrm{mb}$ and a full barb is $2 \mathrm{~m} / \mathrm{sec}$. The dashed lines are reproduced from the lower figure. The chain line and arrow indicates the path of minimum anomaly pressure. The space extrapolation is made to obtain this figure.

other than observing stations are the extrapolated wind obtained by time and space transformation method.

It is obvious that the distribution in Fig. 20 is approximatly the same as that given in Fig. 18 except that the pressure contrast is much stronger for the former. Anyhow we can obtain quite a characteristic mesoscale disturbance whose scale (or the wave length) is about $170 \mathrm{~km}$ in the direction of propagation. The heavy chain line and arrow indicates the path of minimum pressure of mesoscale depression which will be referred to as the path of depression in the following discussions. 


\section{Some quantitative analyses and discus- sions on the dynamical balance}

Before discussing results of quantitative analyses it will be necessary to mention briefly about the network and the treatment of the higher order dynamical quantities such as divergence and vorticity. In Fig. 21 are given the selected stations and networks by which the field of motion on the surface is analysed. The name and the area of each triangular or quadrangular network are entered with the indication of the geometric center by cross symbols. It is noted that the size of network is distributed in such a wide range that the largest one is about 6 times of the smallest one.

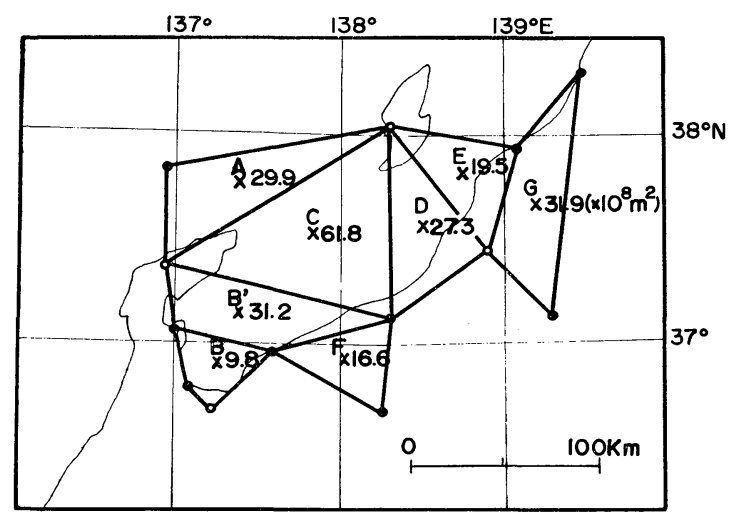

Fig. 21. Surface wind observation networks used for dynamic analysis. Figures show the area of each network in $10^{8} \mathrm{~m}^{2}$ unit. White circles indicate the rawinsonde observation stations.

As is well known, the magnitude of divergence or vorticity depends very much on the size of the network by which it is computed. Especially for the purpose of discussing a mesoscale phenomenon the non-uniformity of the network size might have a sensitive effect on the quantitative analysis. The higher order quantities such as derivatives, say divergence, vorticity etc., are essentially obtained only as average value over a certain area, and the averaging process generally reduces the amplitude of disturbances to a smaller value than the true value when the disturbance assumes a wave-like distribution. The amplitude reduction factor of two dimensional averaging operation is easily obtained for a harmonic distribution $\sin 2 \pi x / L \cdot \sin 2 \pi y / L$ with the wave

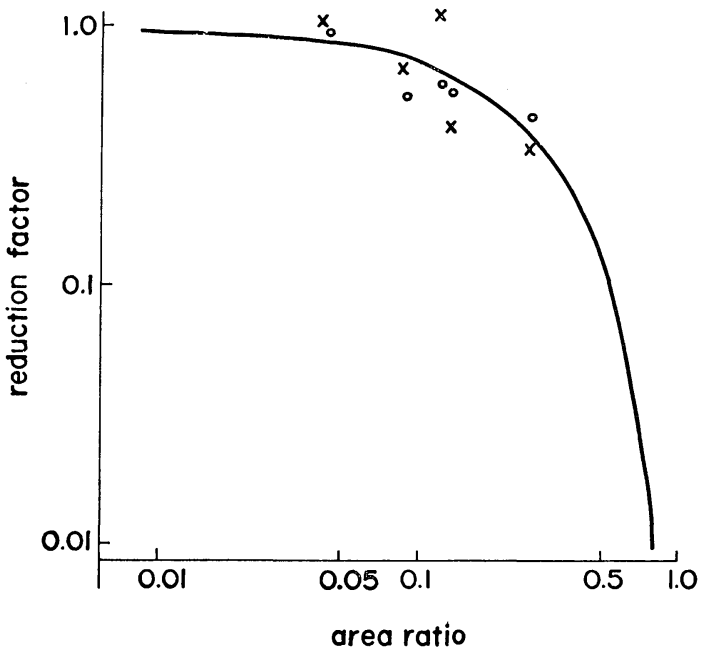

Fig. 22. The amplitude reduction factor of space mean as a function of area ratio. Cross symbols and circles show the amplitudes of divergence and vorticity computed by various networks shown in Fig. 21.

length $L$ in both of $x$ and $y$ axis. Denoting the two dimensional scale of the disturbance and that of the averaging area by $S$ and $S_{1}$ respectively and equating $S_{1} / S=\left(L_{1} / L\right)^{2}$ we easily obtain the reduction factor $\left(\sin L_{1} /\right.$ $L)^{2} \cdot\left(L_{1} / L\right)^{-2}$ which is a function of area ratio $S_{1} / S$. A curve given in Fig. 22 is the reduction factor in logarithmic scale as a function of of area ratio in logarithmic scale.

In case the scale of disturbance $S$ is not known a priori, we can estimate it by the following procedure. Plotting the amplitudes of divergence or vorticity as a function of $S_{1}$ the sizes of computation networks in both logarithmic scale, we can find a best fit to the curve given in Fig. 22 by which the scale $S$ is estimated. The circles and cross symbols on Fig. 22 show the actually computed values under the assumption of steady movement. Thus the estimated value of $S$ is $250 \times 10^{8} \mathrm{~m}^{2}$ which is reasonable since the wave length in the direction of propagation is $170 \mathrm{~km}$ as mentioned in section 6 .

We obtain the anormaly divergence and vorticity field at 09 LST January 16 as shown in Fig. 23 and Fig. 24 by applying the correction of amplitude reduction and the spacetime transformation technique. Contours in these figures are drawn in every $0.5 \times 10^{-4} \mathrm{sec}^{-1}$ unit, and areas of convergence and positive 


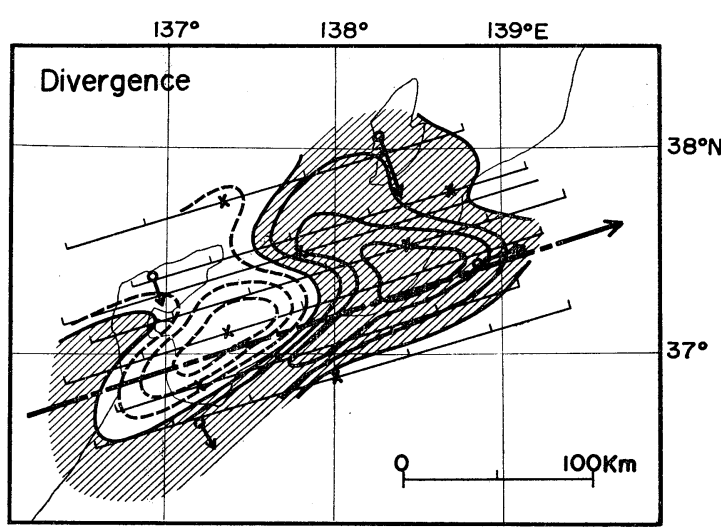

Fig. 23. Anomaly divergence field on the surface at 09 LST January 16,1965 . Contours are given in every $0.5 \times 10^{-4} \mathrm{sec}^{-1}$ and the area of convergence is hatched. The chain line are arrow is the path of minimum pressure given in Fig. 20. Parallel lines passing cross symbols are the coordinates used for extrapolating the values at cross symbols. Small arrows given at four rawinsonde stations (shown by circles) are the wind shear vectors in the lowermost layer.

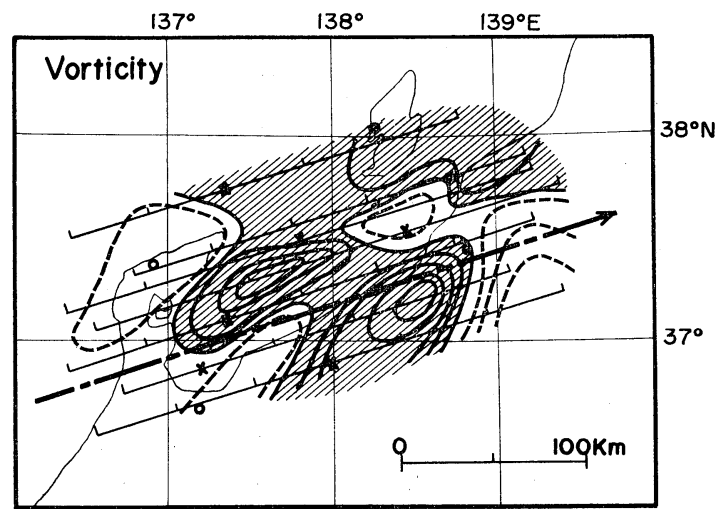

Fig. 24. Anomaly vorticity field on the surface. The area of positive vorticity is hatched. Otherwise the same as in Fig. 23.

vorticity are hatched. Both of divergence and vorticity field are seen to have maximum absolute values of the order of $2 \times 10^{-4} \mathrm{sec}^{-1}$ which is widely recognised as a characteristic value for this scale of disturbances. Fig. 25 shows the distribution of $(1 / \rho) \nabla^{2} p$ computed from the anormaly surface pressure field given in the lower figure of Fig. 20. The heavy chain line and arrow entered in Figs. 23, 24 and 25 is the path of depression reproduced from Fig. 20.

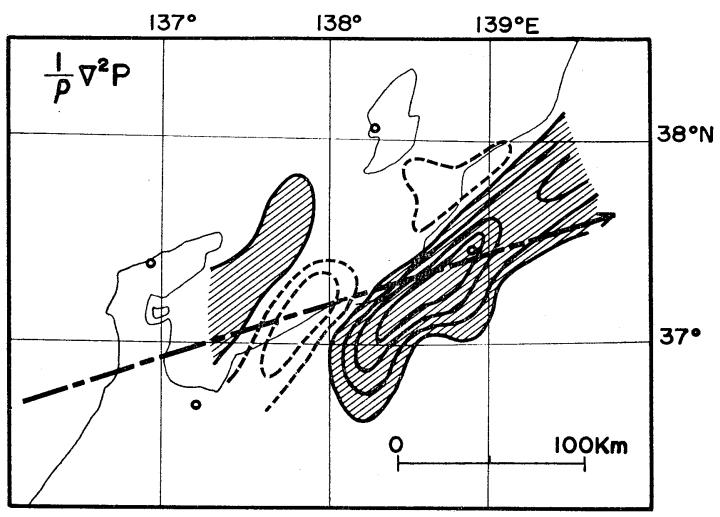

Fig. 25. $(1 / \rho) \nabla^{2} p$ field computed from the anomaly pressure given in the lower figure of Fig. 20 . Contours are given in every $5 \times 10^{-8} \mathrm{sec}^{-2}$ and the area of positive value is hatched.

We can now discuss the balances among various dynamical quantities. It would be better to deal with the vorticity equation and the divergence equation instead of the momentum equation in discussing physical mechanism of mesoscale and convective phenomena since the scalar quantities, $\zeta$ and $D$, are free from directionality. The vorticity equation and the divergence equation relevant to the mesoscale system are written.

$$
\begin{aligned}
\frac{\partial \zeta}{\partial t} & +\boldsymbol{V} \cdot \nabla \zeta+w \frac{\partial \zeta}{\partial z}+w_{x} v_{z}-w_{y} u_{z}+(f+\zeta) D \\
& =F_{1}-\overline{w^{\prime} \frac{\partial \zeta^{\prime}}{\partial z}}
\end{aligned}
$$

and

$$
\begin{aligned}
\frac{\partial D}{\partial t} & +\boldsymbol{V} \cdot \nabla D+w \frac{\partial D}{\partial z}+w_{x} u_{z}+w_{y} v_{z} \\
& +\frac{1}{2}\left(D^{2}+a^{2}+b^{2}-\zeta^{2}\right)-f \zeta+\frac{1}{\rho} \nabla^{2} p \\
& =F_{2}-\overline{w^{\prime} \frac{\partial D^{\prime}}{\partial z}}-\frac{1}{2} \overline{D^{\prime 2}}
\end{aligned}
$$

respectively where $a=u_{x}-v_{y}$ and $b=v_{x}+u_{y}$ are deformation and other symbols are all conventional. All terms on the left hand side of eqs. (1) and (2) are concerned to the characteristic field of mesoscale phenomena* and the terms on the right hand side represent the effect of friction and the significant con-

* The validity of eliminating the synoptic scale field in eqs. (1) and (2) is immediately verified from the order of magnitude. (See fig. 26.) 
tributions of convectional activity respectively. Applying the time space transformation technique, the time change terms are approximated by

$$
\frac{\partial}{\partial t} \simeq-V \frac{\partial}{\partial s}
$$

where $V$ and $s$ are the propagation velocity and direction of the system. As was mentioned before, we obtained $V=23 \mathrm{~m} / \mathrm{sec}$. Therefore, the horizontal advection terms have roughly one order smaller values and are to be neglected against the time change term. The vertical derivative of vorticity and divergence is approximated by an appropriate assumption with the aid of information obtained from 4 point aerological observation. While the vertical derivative of velocity components is obtained directly from observation.

In Fig. 26 are shown the distributions of each term of vorticity equation along the path of depression. It is seen that the local time
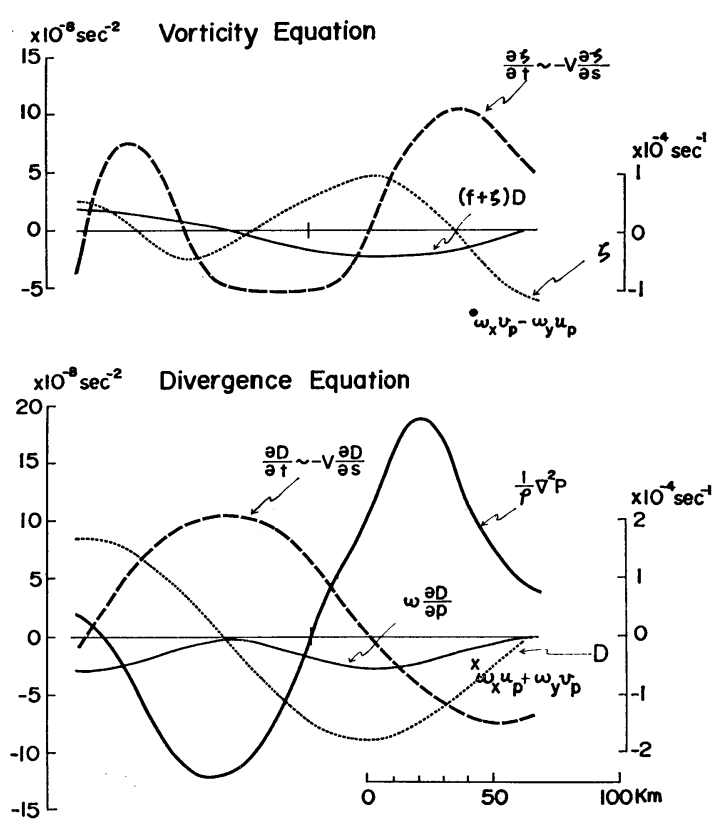

Fig. 26. The distribution of each term of vorticity equation (upper figure) and divergence equation (lower figure) along the path of minimum pressure. The scales are given on the left. Dotted lines are given to show the vorticity field (upper figure) and the divergence field (lower figure) the scales of which are given on the right. A circle and a cross symbols indicate the values of twisting term at those particular locations. change $\partial \zeta / \partial t \simeq-V(\partial \zeta / \partial s)$ has the value of $\pm 10 \times 10^{-8} \mathrm{sec}^{-2}$ but the effect of divergence $(f+\zeta) D$ is one order smaller. The most significant contribution is expected on the twisting term $w_{x} v_{z}-w_{y} u_{z}$. Using the observation at Nagaoka which is located on the path of depression under consideration, we obtained the value indicated by a circle in Fig. 26 . The physical explanation on this matter will be given as follows. The wind shear vectors given by arrows in Fig. 23 indicates that the horizontal vortex tube lies perpendicular to the path in its vicinity. Since the maximum convergence and therefore the maximum upward motion is found there, the increase of positive vorticity and negative vorticity are expected on both side of the path. Actually we can find the vorticity distribution favorable to the reasoning given above.

Next let us study the balance of divergence equation. In Fig. 26 are also shown the distributions of various terms of divergence equation. The local time chang $\partial D / \partial t \simeq V(\partial D / \partial s)$ again has the value of the order of $\pm 10 \times 10^{-8}$ $\mathrm{sec}^{-2}$ which is, as a first approximation, ballanced with the pressure term $(1 / \rho) \nabla^{2} p$. Other terms are all one order smaller at most. This situation is characterized by the gravity wave which was implied in the previous paper. The phase relationship between the pressure field and divergence field given by dotted line in the lower figure of Fig. 26 agrees well with the experimental facts obtained by numerical analysis (Senshu, 1961; Matsumoto and Ninomiya, 1965) and by numerical experiment (Matsumoto, 1966). In other words, the pressure disturbance is related to the upheaving of boundary surface caused by convergence in the underlying fluid.

It is worthwhile to notice the antisymmetrical distribution in the balance mentioned above. Namely the value of $(1 / \rho) \nabla^{2} p$ in the low pressure area amounts to as much as $20 \times 10^{-8} \mathrm{sec}^{-2}$ because of the deepness of depression. We can not find any other terms to overcome this value. Therefore, even by summing up major terms, a large amount of residue will be remained. The distribution of this residual term is given in Fig. 27. A similar discussion was made by Syono et.al. (1959). They made some quantitative analyses on the vorticity equation and the diver- 


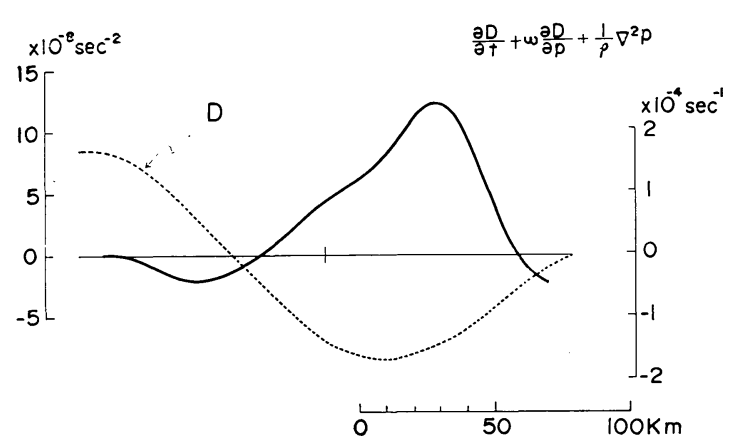

Fig. 27. The distribution of principal residual term of divergence equation is given by full line. The distribution of divergence is reproduced for the sake of comparison.

gence equation by using the data of a presummer heavy rainfall and pointed out that the mean absolute values of all terms in the equation except the pressure term $(1 / \rho) \nabla^{2} p$ are of the order of $10^{-9} \mathrm{sec}^{-2}$ or smaller but that of $(1 / \rho) \nabla^{2} p$ is one order larger. It was implied from this fact that attentions should be given on the irrotationality of frictional force.

The circumstance mentioned above seems to be well explained by introducing the effect of convective activity. Before doing so, let us consider the order of frictional dissipation in a conventional manner. Elliott et al. (1965) computed the mixing loss of vorticity by using serial rawinsonde data of smaller network and obtained the value of the order of $10^{-9} \mathrm{Sec}^{-2}$. The estimated value of the kinematic coefficient of eddy viscosity for vertical mixing is then of the order of $10^{6} \mathrm{~cm}^{2} \mathrm{sec}^{-1}$, one order larger than that used in numerical studies of largescale motions. If we apply the Guldberg-Mohm's type of surface friction, the frictional dissipation both of vorticity and divergence is estimated to be of the order of $10^{-8} \mathrm{sec}^{-2}$. Therefore the frictional terms $F_{1}$ and $F_{2}$ in eqs. (1) and (2) cannot play important role in the mechanism of our system and will be neglected in the following discussions.

Now the important role of the convective activity will be ellucidated as follows. The residue of the divergence equation is compared in Fig. 27 with divergence field. As was mentioned above, the large values in the residual field is observed in the area of large con-

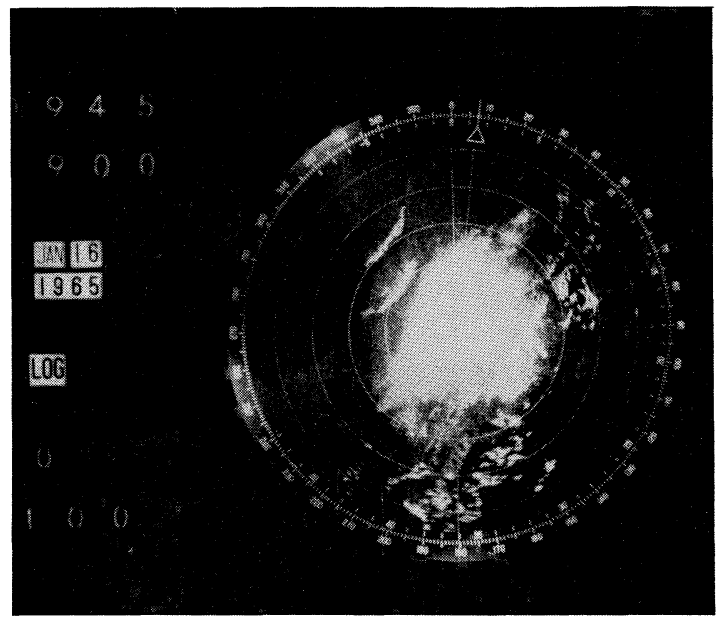

Fig. 28. The radar echo of Mt. Yahiko at 09 LST January 16, 1965 . The range is $100 \mathrm{~km}$. As to the ground echo, the Sado Island and the coastal line should be remarked.

vergence. However in the area of divergence, we find much smaller residues. It would be quite natural to infer that the convective motion is activated in the mesescale convergent field and exerts a prominent dissipating effect. As a matter of fact, widely distributed radar echoes observed in the same region (Fig. 28) tell us the existence of prevailing convective activity. In eqs. (1) and (2), only a representative term is retained on their right hand side. If the convective effect is included in the frictional term, the irrotationality of frictional force mentioned above is explained favorably since it is reasonable to expect a high correlation between upward motion and convergence from the mechanism of convection. The upward motion of convection, on the other hand, is not necessarily correlated with the rotational motion because of the smallness of its scale.

According to Atlas et.al.'s (1965) observation of cumulus it is known that $-\bar{w}^{\prime}\left(\partial D^{\prime} / \partial z\right)$ $\simeq \overline{w^{\prime}\left(\partial^{2} w^{\prime} / \partial z^{2}\right)}$ has positive value in the lower layers. This positive value in the convective region is to balance with the excess positive value of $(1 / \rho) \nabla^{2} p$ or low pressure. Then the negative value of $-\overline{w^{\prime}\left(\partial D^{\prime} / \partial z\right)}$ in the upper layers might possibly require the excess negative value of $(1 / \rho) \nabla^{2} p$. This inference seems to be verified by the vertical distribution of $\nabla^{2} g z$ in Fig. 29 which is obtained by the dense smaller scale aerological observation at 09 LST 


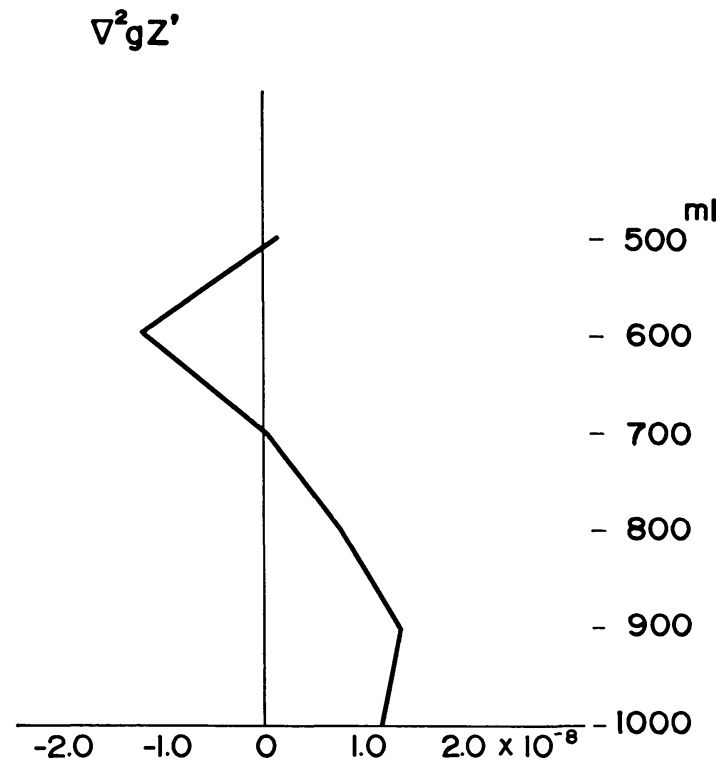

Fig. 29. The vertical distribution of $\nabla^{2} g z$ computed by rawinsonde observations at Aikawa, Toyama, Nagaoka, Sendai and Tateno at 09 LST January $16,1965$.

January 16 in the area under consideration.

Let us finally try to make some quantitative discussions on the value of correlation

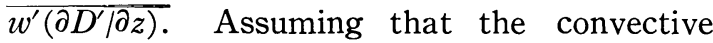
vertical velocity in the environmental area is ignored against the mesoscale vertical velocity we obtain the approximate relationship (c.f. Matsumoto, 1966)

$$
\overline{w^{\prime} \frac{\partial D^{\prime}}{\partial z}} \simeq w \Delta \frac{\partial D^{\prime}}{\partial z}\left(1-\frac{\sigma_{c}}{\sigma_{0}}\right)
$$

where $\Delta$ denotes the difference of the values between the updraft core region and the environmental region of a convective cell and $\sigma_{c} / \sigma_{0}$ is the area ratio of core region to the whole system. Substituting the characteristic value of $w, 20 \mathrm{~cm} / \mathrm{sec}$, estimated from the mesoscale convergence field in Fig. 27, and assuming the value of $\Delta\left(\partial D^{\prime} / \partial z\right)$ to be of $-5 \times 10^{-9} \mathrm{~cm}^{-1} \mathrm{sec}^{-1}$ from the information of Doppler measurment by Atlas et al. (1965), we obtain a fairly promissing value of $\left.-\overline{w^{\prime}\left(\partial D^{\prime} / \partial z\right.}\right) \simeq 10^{-7} \mathrm{sec}^{-2}$ to obtain the balance of divergence equation. Contribution of the term $-(1 / 2) \overline{\left(D^{\prime 2}\right)}$ is always negative and seems to have smaller value in the lower levels. Other terms are not considered here because rotation and deformation could generally be neglected against divergence in the field of convective motion.

\section{Concluding remarks}

Heavy snowfalls were observed just before the north-westerly monsoon started. Because of a sudden pressure rise, synoptic meteorologist was likely to analyse a cold front on their routine weather maps. However, inspecting the case in more detail, we found that the phase velocity of the disturbance was much faster than that of synoptic scale phenomena and that the intensity was concentrated in a mesoscale area. It should be dealt with as mesoscale disturbances rather than as a frontal phenomenon.

In contrast with the summer time precipitation such as thunderstorm, the so-called "meso high" pointed out by Fujita (1955) does not play a significant role probably because the effect of evaporative cooling is smaller for our situation where the temperature is low and the dry air is found only in a limited area of the lowermost thin layer.

Informations obtained by making synoptic and dynamic analyses on the heavy snowfall in January 16, 1965, are summarized as follows.

1) We can find a cold vortex which has been recognized as a necessary condition of heavy snowfall. The scale of the cold dome is extremely small.

2) A well defined stable layer in the rear part of the cold dome has a steep upslope towards the center with remarkable undulation.

3) A family of mesoscale disturbances bringing heavy snowfall is observed in the rear part of the cold dome, and it foreruns the onset of north-westerly monsoon.

4) The steering current of the mesoscale disturbances, and that of echo cells too, is found within the cold air.

5) The dense rawinsonde network revealed the existence of mesoscale convective system, having convergent and positive vorticity field in the lower layers and divergent and negative vorticity field in the upper layers of the cold dome, in relation to the heavy snowfall.

6) The scale, the phase velocity and the life time of the disturbances are about $250 \times 10^{8} \mathrm{~m}^{2}, 85 \mathrm{~km} / \mathrm{hr}$ and 10 hours respective$1 y$. 
7) The phase and amplitude of disturbance pressure field and divergence field characterize the feature of gravity wave.

8) The vorticity change and the divergence change of mesoscale anomaly field seems to balance principally with the twisting term and the pressure term respectively.

9) It is suggested that an important role of convective activity is found in the field of mesoscale convergence where the convective mixing exerts an effect of irrotational friction.

\section{Acknowledgments}

The authors wish to express their thanks to Dr. K. Takahashi and Staff Members of Tokyo Meteorological Observatory and Japan Meteorological Agency for their encouragements particularly in carrying out the project observations. They also thank to the members of Heavy Snow Storm Research Group for many invaluable discussions and informations.

\section{References}

Atlas, D., J. Aoyagi and R. Donaldson Jr., 1965 : Doppler analysis of the physical dynamics of a convective storm. Proceedings of the Intern. Conf. on Cloud Phys., Tokyo and Sapporo, 314318.

Elliott, R. and E. Hovind, 1965 : Heat, water and vorticity balance in frontal zones. $J$. appl. Meteor., 4, 196-211.

Fujita, T., 1955: Results of detailed synoptic studies of squall lines. Tellus, 7, 405-436.

Fujita, T., H. Newstein and M. Tepper, 1957 : Mesoanalysis-an important scale in the analysis of weather data. Res. Paper No. 39, Washington, D.C., U.S.W. B., 83 pp.

Fukuda, K., 1960: Heavy snowfalls in Japan. (in
Japanese) J. Japanese Soc. of Snow and Ice, 22, 73-81.

- 1965: Synoptic study on the mechanism of heavy snowfall. Geophys. Mag., 32, 317-359.

Matsumoto, S. and K. Ninomiya. 1963: Errors in numerical analysis using three observing stations. J. meteor. Soc. Japan, 41, 299-304.

Matsumoto, S., T. Asai, K. Ninomiya, M. Iida and M. Takeuchi, 1965: Behavior of the extraordinary cold vortex over the Far East coastal area observed during the period from Jan. 22 to Jan. 24, 1963. Ibid, 43, 100-115.

Matsumoto, S. and K. Ninomiya, 1965: Meso-scale disturbance observed in the vicinity of a cold vortes center. Papers in meteor and Geophys., 16, 9-22.

Matsumoto, S., 1966 a: Static stability adjustment of an adiabatic quasi-nonlinear model. Ibid., 17 ,

- $1967 \mathrm{~b}:$ Budget analysis on the sea effect snow observed along the Japan Sea coastal area. J. meteor. Soc. Japan, 45, 53-63.

Miyazawa, S., 1961: On the meso-analysis of local disturbances in winter over Northern Hokuriku District. (in Japanese) Tenki, 8, 389-394.

Miyazawa, S., 1962: Study on the heavy snowfall in Hokuriku District Forecasting of the so-called Sato Yuki. (in Japanese) J. Meteor. Research, 14, 703-718.

- 1966: Study on the heavy snowfall in Hokuriku District (4)-Vortical meso scale disturbances during heavy snowfall and rainfall(to be published)

Senshu, T., 1961: Analysis of a meso-scale disturbance on 30 Jan. 1955 in Western Japan. J. meteor Soc. Japan, 39, 59-81.

Syōno, S., K. Miyakoda, S. Manabe, T. Matsuno, T. Murakami and Y. Okuta, 1959: Broad-scale and small scale analyses of a situation of heavy precipitation over Japan in the last period Baiu season 1957. Japanese Journ. Geophys., 2, 59-103. 


\title{
寒冷渦中心付近に観測される中規模擾乱の 3 次元的構造に関する総観的・カ学的解析
}

\author{
松本 誠一・二宮 洸三・秋山 孝子
}

気像研究所

1965 年 1 月 16 日, 日本列島を通過した規模の小さい寒冷渦の西側飞, 一群の顕著な中規模挸乱が観測された。寒 気は鋭い逆転層で境され，その逆転層の西側の斜面と中規模の凹凸が重っていた。現業高層観測網の $1 / 5$ 程度の面積

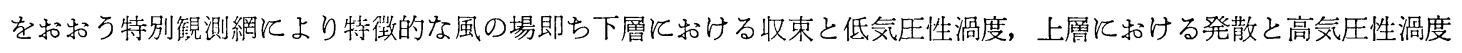
という中規模の刘流系が見出された。これに対応して気圧場にも低層の低気圧高層の高気圧が解析される。

地上気圧場飞は, 周期 $2 \sim 3$ 時間で時速 $85 \mathrm{~km}$ で東進する一連の擾乱があり, 降水と密接飞関連していた。この損 乱を抽出するために $2 \cdot 5$ 時間移動平均よりの偏差值をとり, 気圧および風の偏差場と対して許細な量的解析を試み た。擾乱の規模は $250 \times 10^{8} \mathrm{~m}^{2}$ 程度のものであった。気圧負偏差域飞 $1 / 4$ 波長扔くれて収束域が続き, その南飞正 渦度北㳊珮度を伴っている。從って渦度方程式飞扮ける主要な均合いは, 渦度変化と起上り項の間飞樹立されてい る。一方発散方程式の均合いは, 前の論文で示した通り第 1 近似としては発散变化と気圧場との間で成立っている。 然しながら，収束域に扔いて大きな不一致が認められる。この事実は，その領域内に括汀る積雲対流の効果を考える ことによって都合よく説明される。

なお，本研究は気象研究所北陸豪雪の研究の一部として行なわれたものである。 